\title{
THE ROLE OF FAMILY NETWORKS AND GENDER ON BORROWING BEHAVIOR IN INDONESIA
}

\author{
Meliyanni Johar \\ Anu Rammohan \\ University of Technology Sydney, University of Western Australia, Australia
}

\begin{abstract}
In this paper, we use the nationally representative Indonesian Family Life Survey dataset (IFLS-3), to examine if access to loans from informal networks such as family and friends influences borrowing behavior in formal credit markets. Our empirical results show that there is a gender dimension to borrowing behavior, with females being more likely to receive loans from family members. However, access to loans from family does not lower their propensity to seek out formal credit. For males, access to family loans does not affect borrowing propensity but it increases the size of borrowing from the formal sector. From a policy perspective, our results indicate that education plays an important role in improving an individual's access to financial credit markets and reducing their dependence on internal networks.
\end{abstract}

JEL Classifications: 016, C25

Keywords- Indonesia, family networks, gender

Corresponding author's Email address: anu.rammohan@uwa.edu.au

Acknowledgment: Anu Rammohan gratefully acknowledges support from an Australian Research Council Discovery Project grant.

\section{INTRODUCTION}

Access to formal sector loans is typically contingent on factors such as an individual's repayment ability, their ability to meet the collateral requirement, and the institution's perception of their creditworthiness. These issues are further compounded in developing countries with high levels of poverty, where the poor and the less-educated, who represent large sections of the population, are often priced out of the formal credit markets. These factors affect females relatively more because they tend to be overrepresented among the poor. Although governments and non-governmental organizations in many developing countries through microcredit programs have attempted to promote microenterprise or income generation activities, studies from Bangladesh (Webb et al, 2002; Halder and Mosley, 2004), show that the ultra-poor lacking livelihood resources are reluctant to borrow due to their fear of being overburdened. They were moreover, found to have a fear of the cash economy. For example, Webb et al. (2002) find that $84 \%$ of the poor women in their sample refused to borrow because of their fear of debt, and due to their concerns of other people's perception of them being in debt. Similarly, in a recent study from Indonesia, Johnston and Morduch (2007) find that in their sample, nearly half of the creditworthy poor households were averse to taking debt and did not 
seek credit. The incidence of debt aversion was found to be relatively stable across income groups.

Under these circumstances, informal networks, such as friends and family members, often play an important role in supporting the credit needs of low-income individuals who lack collateral, lack knowledge of formal sector markets or when formal sector markets are unable to meet their credit requirements fully. Alternatively, individuals may simply feel more comfortable borrowing from family members rather than banks due to the administrative process involved in obtaining formal-sector loans. Consequently, access to loans from internal networks may lower the propensity to borrow from formal sector markets. In this paper, using the nationally representative Indonesian Family Life Survey dataset (IFLS-3), we examine if access to loans from informal networks such as family and friends influences borrowing behavior in formal credit markets. We first analyze how family networks shape an individual's expectations of being able to borrow internally. Then, conditional on this expectation, we investigate an individual's knowledge of formal credit markets and their likelihood of borrowing from formal credit sources.

Despite the advantages of family networks as a source of credit (e.g., quick to obtain with little or no administrative cost), it is ultimately a risky strategy since it increases the vulnerability of borrowers to exogenous economic shocks in the event of unavailability of credit from family members. This is particularly true if family members face similar economic circumstances. Furthermore, individuals who rely heavily on family transfers to satisfy their credit requirements may have few incentives to seek formal credit. However, access to formal sector credit has many advantages such as fostering greater independence, promoting greater repayment discipline and giving individuals the opportunity to access larger loans. Another consideration is that in our dataset, females tend to rely on internal loans relatively more than males do and have a lower likelihood of being able to identify a formal sector lender. ${ }^{1}$ The impact of access to internal loans on borrowing behavior in the formal credit market is also different for males and females. To explore these gender differences more fully, we conduct separate analysis for males and females.

Our analysis has policy implications on the issue of whether to target female borrowers. Developing countries such as Bangladesh, Bolivia and India have extended microcredit programs to women as a key strategy for poverty alleviation by encouraging formation of micro-enterprises. In Indonesia, despite the plethora of microcredit institutions and the success of the cooperative-style bank BRD (Bank Rakyat Desa) and the state-owned people's bank BRI (Bank Rakyat Indonesia) in initiating small business, a national-level microcredit program targeted at women is lacking. The share of female borrowers in BRI, the largest provider of microcredit (i.e., small credit up to Rp.50 million (US\$9262)) in the country, is low, and has in fact declined from 24\% in 1996 (Ravicz, 1999) to $18 \%$ in 2002 (Khawari, 2004). Nevertheless, there is evidence that females are willing to participate in microcredit initiatives (Ravicz, 1999). Our results suggest that policies which specifically target females can help in alleviating their excess demand for loans. 


\section{LITERATURE REVIEW}

Indonesia has a number of microfinance programs that provide financial services to low income households. The main microfinance (MFI) providers in Indonesia include Bank Rakyat Indonesia (BRI), Badan Perkreditan Rakyat (BPR), private banks, cooperatives (e.g., Koperasi Unit Desa (KUD)), semi-formal financial institutions (e.g., Lembaga Dana dan Kredit Pedesaan (LDKP) and Badan Kredit Desa (BKD)), International bodies (e.g., the World Bank), the national pawnshop (Perum Pegadaian, $\mathrm{PP})$, and the national post office.

The largest microfinance provider is the Village Bank operated by BRI (BRIUD), whose vast and deep outreach is in part due to its successful saving mobilization initiatives which lowers the cost of credit provision to rural areas. However, in terms of access to credit, key shortcomings of the BRI-UD are that loans are typically made to the better-off among the poor and to established entrepreneurs. Furthermore, borrowers are required to put up collateral, although the collateral in this context is often defined loosely, and the banking staff are allowed some discretion to increase the loan size for reliable borrowers that lack collateral. The BRI also charges net annual effective interest rates of approximately 32\%, and allows clients to borrow upto a maximum of Rp 50 million (Johnston and Morduch 2007). As Takahashi et al (2010) note, although the BRI has an excellent reputation in terms of the number of clients, high repayment rates, and profitability, poor individuals with insufficient collateral and/or those individuals or those whose loan requirements are small, are unable to access credit from BRI. See Hamada (2010) for an overview of the microfinance industry in Indonesia.

Thus, individuals with insufficient collateral, typically the poor, tend to rely on loans from informal moneylenders at high interest rates or from friends and family, whose supply of funds is likely to be limited (Conning and Udry 2007). Recent studies have questioned whether microcredit programs reduce poverty. Using Indonesian data Takahashi et al (2010) study if microcredit improves the welfare of its clients and whether it helps the poor. They find that although microcredit can potentially contribute to the reduction of intergenerational poverty through schooling investment, its impact on poverty alleviation is limited. Studies from India (Banerjee et al., 2009) and the Philippines (Karlan and Zinman, 2009) also find little evidence of a significant impact of microcredit on poverty reduction. Both Banerjee et al (2009) and Karlan and Zinman (2009) use randomized controlled experiments to evaluate the impact of microcredit on poor households. Banerjee et al. (2009) show that in Indian slums there is no statistically significant difference in expenditures per capita and expenditures on education and health for the group that received microcredit. Karlan and Zinman (2009) similarly show that in the Philippines, there is no statistically significant difference in household income, the probability of being under the poverty line, and the quality of food between the treatment and control groups.

Notwithstanding these shortcomings of the microfinance programs for the poor, the literature has also identified large gender differences in access to formal credit markets (Pitt and Khandker, 1998; Hashemi et al, 1996). It is hypothesized that female borrowers in developing countries face greater constraints in the formal credit markets due to their limited opportunities for wage employment in the formal sector (see Berger, 1989). They are more likely to be employed in the unorganized, informal sector of the economy, self-employed in small-scale farming, domestic services or petty trading (see 
Khawari, 2004; Berger, 1989). Moreover, the share of women borrowers is low in Indonesia's BRI for example, and has declined from 24\% in 1996 (Ravicz, 1999), to $18 \%$ in 2002 (Khawari, 2004). Previous studies have found a strong positive link between women's access to credit and the welfare of their household (Sharma, 2002; Chemin, 2003). In particular, Panjaitan-Drioadisuryo and Cloud's (1999) study of Indonesian married women who had accessed loans from the Small Farmers Development Program (SFDP), ${ }^{2}$ finds that women consistently devote their additional income to more nutritious food, better health care and education for their children. These authors find that women are more creditworthy relative to men, as the program recorded a $17 \%$ higher repayment rate relative to BKK (Badan Kredit Kecamatan), which also lends to men. By exploring if there is a gender dimension to borrowing in formal markets, our analysis fills a gap in the literature on credit markets in Indonesia (see previous studies by Okten and Osili, 2004; Panjaitan-Pradisuryo and Cloud, 1999; Gertler et al, 2001). Gender-induced differences in borrowing behavior arise if potential female borrowers have lower education and income levels relative to males, and a lower attachment to the labor market. Since these factors are typically used by formalsector lenders to assess the creditworthiness of potential borrowers, we expect to observe relatively more females than males borrowing from internal networks.

\section{DATA AND ESTIMATION STRATEGY}

The data for this study comes from the Indonesian Family Life Survey (IFL3) conducted in 2000. The IFLS3 is a nationally representative random sample survey, covering thirteen of the 27 provinces, where approximately $83 \%$ of the population resides. The data are unique and ideal for our analysis. It contains data on an individual's economic and labor market characteristics, their household-level demographic characteristics and also detailed information at the individual-level on transfers among family members. Furthermore, there is community-level information on infrastructure, such as the availability of financial institutions, and the quality and accessibility of public facilities in the community.

The analysis in this paper is based on 25,250 adults (aged 15 years and above) for whom complete information is available on our variables of interest. The summary statistics of all the variables used in the analysis are reported in Appendix A. Overall, $34 \%$ of the sample received at least one internal loan in the last 12 months prior to the survey. ${ }^{3}$ The differences in these descriptive statistics by gender are noteworthy, as discussed in the introduction. We observe that $73 \%$ of the sample is aware of at least one source of formal credit (e.g., banks or non-bank institutions like cooperatives and employers $)^{4}$, though the figure is lower among female respondents where we observe only $68 \%$ being able to identify a formal source of credit. We note that $13 \%$ of these individuals ( $10 \%$ of the sample) made at least one attempt to borrow from a formal credit institution during the year. Questions on borrowing behavior were only asked conditional on knowledge.

While $36 \%$ percent of females in our sample borrowed from internal networks, the figure is $30 \%$ for males. Relative to males, a smaller proportion of females have knowledge of formal credit sources and borrowed from this source. Females also tend to borrow a much lower amount relative to males. For example, the size of a loan made to females on average is less than half the size of a loan made to males. We note that 
the data only records the amount of loans received by individuals which may not be the same as the amount that they had asked for. Nevertheless, to the extent that individuals can have multiple borrowing attempts (perhaps from other formal lenders) during the year, the total amount of loans would be representative of the amount required by the respondent. Of all applicants, only 40 applicants (1.6\%) made an attempt and did not receive any loan by the end of the year. Unfortunately, no further information is available on these individuals, particularly with regards to whether they stopped after the failed attempt, or whether they attempted to borrow again but did not succeed. In our data we do not observe the interest rates faced by the individual in the formal and informal credit markets nor do we observe the size of internal loans. What we do observe are individuals' demographic, socio-economic characteristics, and residential characteristics. These observables may reflect variations in income, and cost of borrowing from external sources. Furthermore, those individuals with higher income levels, better ability to access information on external borrowing (e.g., those with better work-networks, labor market attachment) will have lower external borrowing costs. While the other demographic characteristics are approximately similar across both females and males, only $11 \%$ of the female respondents in our sample are household heads, whereas the figure is $60 \%$ in the case of males.

In sub-sections below we describe our econometric strategy. Our analysis consists of two parts. Firstly, we explore the formation of individual expectations of receiving an internal loan. Limited empirical studies exist to give us precedent over what factors influence internal borrowing behavior. We anticipate that the respondent's individual and economic characteristics and the number of internal networks will influence internal loans. Secondly, we present an econometric model to analyze how the expectation of internal loans affect an individual's propensity to access information on formal credit opportunities and their likelihood of borrowing from formal markets.

\section{Expected access to internal loans}

We first consider the case in which family lenders do not discriminate among borrowers from their family based on their economic characteristics. Hence, an individual's expectation of receiving an internal loan is a function only of the availability of family members and can be written as:

$E\left(d_{i} \mid \mathrm{X}\right)=\Phi\left(\alpha_{0}+\alpha_{1} P_{i}+\alpha_{2} S_{i}+\alpha_{3}\right.$ female $\left._{i}+\alpha_{4} X_{i}\right)$

where $d_{i}$ is a binary variable indicating whether or not the individual received an internal loan/transfer in the last 12 months. Eqn (1) is estimated using a probit model.

On the right-hand side of equation (1), the terms $P_{i}$ and $S_{i}$ denote parental and siblings' characteristics, respectively. A dummy variable is included to indicate if individuals have made any internal loans to family members in the last 12 months. If it is the case that relatively well-off individuals are more likely to be making internal loans/transfers to family members, then (1) for these individuals would be lower. Certain individuals however may naturally expect higher (or lower) access to internal loans. For example, females are more likely to receive internal loans. Their lower attachment to the labor market and their relatively lower levels of income may make them more inclined to rely on internal networks for their credit requirements. To account for this, we include a dummy variable for the gender of the respondent. The variable female $i$ takes on a value of 1 for females and 0 otherwise. Finally, $X_{i}$ includes 
the respondent's demographic characteristics such as their age, age squared and marital status.

Next we allow individual's economic characteristics to also influence whether or not they receive internal loans. Hence, we re-write equation (1) to also include the economic characteristics of the respondent as below:

$E\left(d_{i} \mid \mathrm{X}, R\right)=\Phi\left(\beta_{0}+\beta_{1} P_{i}+\beta_{2} S_{i}+\beta_{3}\right.$ female $\left._{i}+\beta_{4} X_{i}+\beta_{5} R_{i}\right)$

where the term $R_{i}$ denotes a [ $1 \mathrm{x} j$ ] vector of $j$ variables that reflect an individual's economic characteristics, such as their assets, their educational attainment and their employment status. The effect of these measures on the likelihood of obtaining internal loans is ambiguous. For example, better education, higher assets and better employment reflect individuals' higher repayment ability, which may make family members more likely to lend to them. However, these variables are also likely to increase an individuals' knowledge of formal financial markets, and their ability to access formal sector loans, which makes them less likely to rely on internal loans.

\section{Propensity to seek information on formal(non-family) loan sources}

To test the relationship between expected access to internal loan and borrowing behavior in the formal credit markets, we estimate the following equation:

$$
k_{i}=\theta_{0}+\theta_{1} \hat{d}_{i}+\theta_{2} \text { female }_{i}+\theta_{3} X_{i}+\theta_{4} R_{i}+\theta_{5} H_{i}+\theta_{6} Z_{i}+v_{i}
$$

In equation (3), the term $k_{i}$ denotes a respondent's awareness or knowledge of external credit sources. The term $\hat{d}_{i}$ refers to the endogenous expectation of receiving an internal loan. Conceptually, borrowing behavior in the formal credit markets take into account the probability of getting internal loans $\hat{d}_{i}$. If $\theta_{1}<0$ then accessibility to internal loans reduces the gains from searching for external loans, such that individuals would be less likely to know of external loan providers. Furthermore, our raw data suggesting that females are less knowledgeable of external borrowing options would be confirmed if $\theta_{2}<0$. The terms $X$ and $R$ are defined as before, while $H$ denotes additional control variables reflecting an individual's potential information channels such as spouse's characteristics, household composition, and residential location. Finally, $Z$ denotes village characteristics to capture the level of development in the respondent's village.

To provide consistent and efficient estimates of (3), following Newey (1987) we estimate an Amemiya Generalized Least Square (AGLS) estimator (Adkins, 2008; Maddala, 1983). This estimator provides a consistent estimator of the standard errors for subsequent hypothesis testing of the parameters. The estimation procedure involves estimating a series of probit models (see Adkins, 2009 for details). For example, access to internal loans is estimated as a function of parental and sibling characteristics (instruments) plus all the exogenous variables in (3). The residual and predicted values are then saved to be used in the next stage of the estimations. Specifically, a probit model with dependent variable $k$ is estimated as a function of all covariates as before and the saved residual term. The purpose of this step is to obtain the coefficient on the residual term and the covariance matrix of the coefficients of the remaining covariates. Subsequently, another probit model is estimated with dependent variable $k$ as a function of $\hat{d}_{i}$ (the endogenous probability of getting internal loans and which is 
estimated from the linear model in the first stage), exogenous variables and the residual term. The point of this regression is to obtain the difference of the coefficients on the residuals and $\hat{d}_{i}$ to be used as part of a correction term, which will form the "weights", in the AGLS estimator of (3). ${ }^{5}$

\section{Propensity to apply for loans from formal credit institutions}

Would an individual's expectation of receiving internal loans reduce their propensity to borrow from formal institutions? Recall that we are faced with a sample selection problem, as only those individuals who could identify a formal credit source $\left(k_{i}=1\right)$ were asked further questions on borrowing behavior. For instance, individuals whose credit requirements are high may prefer to borrow from formal lenders and will seek out information on formal credit options. To address this issue, we estimate a censored probit model, where we use village-level characteristics to satisfy the exclusion restrictions. The justification for using these instruments is that the infrastructure conditions at the village-level reflect the local information networks, but do not directly influence an individual's decision to borrow in the formal credit market.

The estimation results from the selection models find evidence for nonrandom selection conditional on covariates, with positive correlation coefficients between the error terms of selection and outcome equations at the $5 \%$ significance level. ${ }^{6}$ However, this selection was driven by the distinct behavior of male and female respondents in a pooled sample, and disappears when we estimate the model separately by gender. The probability that the unobservable-driven selection is negligible is $43 \%$ and $77 \%$ for males and females respectively, and both are much larger than the critical threshold of 5\%. Thus, the outcome (borrowing) equation can be estimated on the knowledgeable population disaggregated by gender.

To test the relevance of internal loans on external borrowing propensity, we estimate

$b_{i}=\delta_{0}+\delta_{1} \hat{d}_{i}+\delta_{2}$ female $_{i}+\delta_{3} X_{i}+\delta_{4} R_{i}+\delta_{5} H_{i}+u_{i}$,

Where $b_{i}$ is a binary variable that takes a value of 1 if individual $i$ made at least one external borrowing attempt(s) (regardless of outcome) in the last 12 months. Equation (4) is also estimated using AGLS.

We are also interested in the issue of whether internal loans are typically used for specific purposes such as for non-business related activity. In other words, is it the case that the expectation of internal loans has little effect on external borrowing behavior for business purposes? In the survey, respondents were asked to identify what they intended to do with their loans from an array of possibilities. One of these possibilities is "borrowing for business". We categorize the variable $b$ into: (i) $b b$ if any loan was intended for business-purposes; and (ii) bn if all loans were for non-business purposes, such as to purchase household goods, pay for ceremonial occasions and daily expenses. Equation (4) is re-estimated with these new dependent variables. In estimating (i), i.e., borrowing for business, those borrowing for non-business purposes are excluded from the sample so that we compare only borrowers for business against nonborrowers. We note that $71 \%$ of loans received by female borrowers are non-business loans, while for male borrowers this share is only slightly lower at $67 \%$. Finally, we test the impact of receipt of internal loans on the size of formal sector loans. OLS 
regressions are therefore estimated on the log scale of these amounts. ${ }^{7}$ The covariates are those used in the borrowing equation (4).

\section{RESULTS}

Our main estimation results are presented in Tables 1-3. In Table 1, we report probit coefficients and marginal effects for the likelihood of accessing internal loans conditional on parent and sibling characteristics, calculated at (gender-specific) sample means. In Table 2, we report the coefficients and marginal effects for the expectation of accessing an internal loan conditional on an individual's economic characteristics. In Table 3, we report the coefficients for $\hat{d}_{i}$ for equations (3) and (4), and the loan amount. As our main focus is on the role of internal loans on borrowing behavior, we report the full set of results in Appendix B.

Initially, we estimated equations (1) and (2) for the full-sample, but found the poolability assumption restrictive. The poolability refers to the assumption that differences between male and female borrowing behavior can be sufficiently captured by a dummy variable for gender. However, the slope estimates are also different for males and females in the sample. In the probit model, the slope coefficients $[\alpha, \beta]$ and scales (overall variance) are inseparable such that differences in either the coefficients or scales, or both, would influence the size of the estimates. ${ }^{8}$ Thus, we estimated the equations separately for males and females, and we computed the predictions based on these estimates. From Table 1, we observe that for an "average" male or female, parental characteristics have a minor effect on expectations of receiving an internal loan. In contrast, the characteristics of non-coresiding siblings are significant determinants of the likelihood of receiving internal loans and transfers. Our analysis indicates that females who have economically active siblings and/or those who are in close contact with their siblings have a greater expectation of receiving internal loans. For males, only the latter effect is statistically significant. However, females with no siblings tend to find it more difficult to obtain internal loans than males in the same situation. We observe that the marginal effect for absence of siblings is slightly larger for females than for males. Compared to females with siblings, those without siblings are 15 percentage points less likely to have access to internal loans.

Interestingly, there is a positive relationship between provision and receipt of internal loans. ${ }^{9}$ A priori we would expect that individuals making loans to family members are relatively wealthier members of families, so it is surprising that they are also more likely to receive loans. The positive relationship, however, suggests that family networks may act as a consumption-smoothing mechanism between its members. Both of these conditions appear to suggest that family members may face similar economic constraints. Married individuals are found to have lower expectations of transfers from their own families relative to respondents in the unmarried or widowed categories. Finally, the effect of age is non-linear, so that the expectation of receiving internal loans decreases until the age of 61 years for males and 64 years for females. In particular, the elderly are more reliant on monetary transfers from family members to finance their consumption. 
TABLE 1. PROBIT ESTIMATES ON EXPECTATIONS OF AN INTERNAL LOAN

\begin{tabular}{|c|c|c|c|c|c|c|}
\hline & \multicolumn{3}{|l|}{ Male } & \multicolumn{3}{|l|}{ Female } \\
\hline & Coeff & (s.e) & $\mathrm{ME}$ & Coeff & s.e & $\mathrm{ME}$ \\
\hline \multicolumn{7}{|l|}{ Parent char. } \\
\hline Mother only & -0.030 & $(0.035)$ & -0.010 & -0.051 & $(0.033)$ & -0.019 \\
\hline Father only & -0.040 & $(0.055)$ & -0.014 & 0.075 & $(0.050)$ & 0.029 \\
\hline None & 0.014 & $(0.070)$ & 0.005 & -0.086 & $(0.062)$ & -0.032 \\
\hline \multicolumn{7}{|l|}{ Sibling char. } \\
\hline \# econ active & 0.029 & $(0.020)$ & 0.010 & 0.056 & $(0.019)^{* * *}$ & 0.021 \\
\hline \# nearby & 0.000 & $(0.011)$ & -0.000 & -0.008 & $(0.010)$ & -0.003 \\
\hline \# seen regularly & 0.029 & $(0.011)^{* * *}$ & 0.010 & 0.028 & $(0.010)^{* * *}$ & 0.011 \\
\hline Mean age & 0.000 & $(0.001)$ & -0.000 & 0.001 & $(0.001)$ & 0.000 \\
\hline No sibling & -0.418 & $(0.049)^{* * *}$ & -0.134 & -0.435 & $(0.043)^{* * *}$ & -0.151 \\
\hline \multicolumn{7}{|l|}{ Individual char. } \\
\hline Provide loan & 0.284 & $(0.028)^{* * *}$ & 0.099 & 0.180 & $(0.026)^{* * *}$ & 0.068 \\
\hline Age & -0.056 & $(0.005)^{* * *}$ & -0.007 & -0.039 & $(0.004)^{* * *}$ & -0.006 \\
\hline Agesq & 0.000 & $(0.000)^{* * *}$ & & 0.000 & $(0.000)^{* * *}$ & \\
\hline Married & -0.192 & $(0.047)^{* * *}$ & -0.068 & -0.219 & $(0.039)^{* * *}$ & -0.082 \\
\hline Separated & 0.166 & $(0.084)^{* * *}$ & 0.063 & 0.097 & $(0.053)^{* * *}$ & 0.038 \\
\hline Constant & 0.900 & $(0.091)^{* * *}$ & & 0.701 & $(0.076)^{* * *}$ & \\
\hline $\log L$ & $-6,996$ & & & $-8,444$ & & \\
\hline Pseudo R-sq & 0.054 & & & 0.035 & & \\
\hline $\mathrm{N}$ & 11,959 & & & 13,291 & & \\
\hline
\end{tabular}


TABLE 2. PROBIT RESULTS ON EXPECTATIONS OF INTERNAL LOANS CONDITIONAL ON INDIVIDUAL'S ECONOMIC CHARACTERISTICS

\begin{tabular}{|c|c|c|c|c|c|c|}
\hline & \multicolumn{3}{|l|}{ Male } & \multicolumn{3}{|l|}{ Female } \\
\hline & Coeff & (s.e) & ME & Coeff & (s.e.) & $\mathrm{ME}$ \\
\hline \multicolumn{7}{|l|}{ Parent char. } \\
\hline Mother only & -0.025 & $(0.035)$ & -0.009 & -0.053 & $(0.033)$ & -0.020 \\
\hline Father only & -0.038 & $(0.055)$ & -0.013 & 0.074 & $(0.050)$ & 0.028 \\
\hline None & 0.005 & $(0.070)$ & 0.002 & -0.082 & $(0.062)$ & -0.031 \\
\hline \multicolumn{7}{|l|}{ Sibling char. } \\
\hline \# econ active & 0.051 & $(0.021)^{* *}$ & 0.018 & 0.071 & $(0.020)^{* * *}$ & 0.027 \\
\hline \# nearby & -0.004 & $(0.011)$ & -0.001 & -0.009 & $(0.010)$ & -0.003 \\
\hline \# seen regularly & 0.031 & $(0.011)^{* * *}$ & 0.011 & 0.028 & $(0.010)^{* * *}$ & 0.010 \\
\hline Mean age & 0.000 & $(0.001)$ & -0.000 & 0.001 & $(0.001)$ & 0.001 \\
\hline No sibling & -0.408 & $(0.051)^{* * *}$ & -0.130 & -0.391 & $(0.044)^{* * *}$ & -0.136 \\
\hline \multicolumn{7}{|l|}{ Individual char. } \\
\hline Provide loan & 0.327 & $(0.029)^{* * *}$ & 0.114 & 0.215 & $(0.026)^{* * *}$ & 0.081 \\
\hline Age & -0.045 & $(0.005)^{* * *}$ & -0.022 & -0.030 & $(0.004)^{* * *}$ & -0.014 \\
\hline Agesq & 0.000 & $(0.000)^{* * *}$ & & 0.000 & $(0.000)^{* * *}$ & \\
\hline Married & -0.150 & $(0.049)^{* * *}$ & -0.052 & -0.248 & $(0.041)^{* * *}$ & -0.094 \\
\hline Separated & 0.179 & $(0.085)^{* *}$ & 0.067 & 0.070 & $(0.054)$ & 0.027 \\
\hline \multicolumn{7}{|l|}{ Economic char. } \\
\hline Log(asset) & -0.038 & $(0.008)^{* * *}$ & -0.013 & -0.057 & $(0.007)^{* * *}$ & -0.021 \\
\hline Primary school & -0.090 & $(0.057)$ & -0.032 & 0.052 & $(0.039)$ & 0.019 \\
\hline Junior high & -0.165 & $(0.063)^{* * *}$ & -0.057 & 0.081 & $(0.049)^{*}$ & 0.030 \\
\hline Senior high & -0.082 & $(0.063)$ & -0.029 & 0.113 & $(0.049)^{* *}$ & 0.042 \\
\hline Post-school & 0.025 & $(0.075)$ & 0.009 & 0.254 & $(0.065)^{* * *}$ & 0.097 \\
\hline Self-employed & -0.226 & $(0.044)^{* * *}$ & -0.082 & -0.049 & $(0.032)$ & -0.019 \\
\hline Unpaid worker & -0.089 & $(0.056)$ & -0.033 & -0.101 & $(0.036)^{* * *}$ & -0.038 \\
\hline Public sector & -0.553 & $(0.068)^{* * *}$ & -0.182 & -0.415 & $(0.078)^{* * *}$ & -0.146 \\
\hline Private sector & -0.258 & $(0.041)^{* * *}$ & -0.093 & -0.153 & $(0.033)^{* * *}$ & -0.057 \\
\hline Constant & 1.567 & $(0.154)^{* * *}$ & & 1.414 & $(0.133)^{* * *}$ & \\
\hline $\log L$ & -6938 & & & -8390 & & \\
\hline Pseudo R-sq & 0.062 & & & 0.041 & & \\
\hline 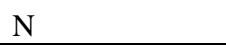 & 11,959 & & & 13,291 & & \\
\hline
\end{tabular}


Table 2 presents results with individual's economic characteristics included in the access to internal loans model. The Log-likelihood Ratio (LR) test of joint restriction that economic characteristics are irrelevant is rejected with ample evidence (i.e., p-value of zero). For both males and females, the provision of loan remains positively related to the receipt of loans, controlling for wealth. However, independent wealth effect is negatively correlated with expectations of access to internal loan. For male respondents, the economic factors act to lower expectations of internal loans. For instance, relative to males with no education, those with Junior High levels of education have lower expectations of receiving an internal loan. For females, on the other hand, while higher wealth and employment status lower expectations of internal loans, higher educational attainment tends to increase their expectations of an internal loan. One possible explanation for this is to do with a J-shaped nexus between education and labor supply for Indonesian women (Widarti, 1998). Other studies using Indonesian data also provide evidence of a non-linear effect of education on working hours (Kim and Aassve, 2006). They find that for less than six years of schooling, there is a positive effect of education on hours worked for females, while for more than six years of schooling, higher education implies reduced hours worked. Hence, it is possible that the women in our sample are better educated, but non-participation in the labor market may restrict their ability to access loans in formal credit markets, thus increasing their reliance on loans from family members. Figure 1 plots the distributions of expected access to internal loans separately for males and females. The gender differences in borrowing behavior are noteworthy, with the distributions for males being more spread out (i.e., have larger variance), while those for females are relatively concentrated around the mean. However, in each group, the expectations of internal loan unconditional and conditional of economic characteristics track one another quite closely, particularly for females.

Table 3 presents the estimation results for equations (3) and (4) and loan amount equation. According to Table 3, better access to internal loans does not lower an individual's propensity to seek out formal credit. Instead, our results indicate that accessibility to internal loans: (i) increases the propensity of individuals to search for external loan sources; (ii) increases the propensity to borrow among females, particularly for non-business purposes; and (iii) increases the amount borrowed by males by an average of Rp.5,400 (2000US\$0.67, calculated at the sample mean of Rp.326,553 or 2000US\$40), for a one percentage point increase in $\hat{d}_{i}$. Thus, our results suggest that the two loan sources are "complementing" one another.

One possible explanation for this may be that our measure of access to internal loans does not sufficiently capture the amount obtainable from internal networks. For instance, we take into account the extent of internal networks. However, it is possible that although individuals from large families have many potential lenders, these lenders can only lend a small amount, even cumulatively. If these individuals require larger loans they then have to borrow from formal credit sources. The dataset has information on the size of the internal loan, but there are many missing values. 


\section{FIGURE 1. EXPECTATIONS OF INTERNAL LOAN}
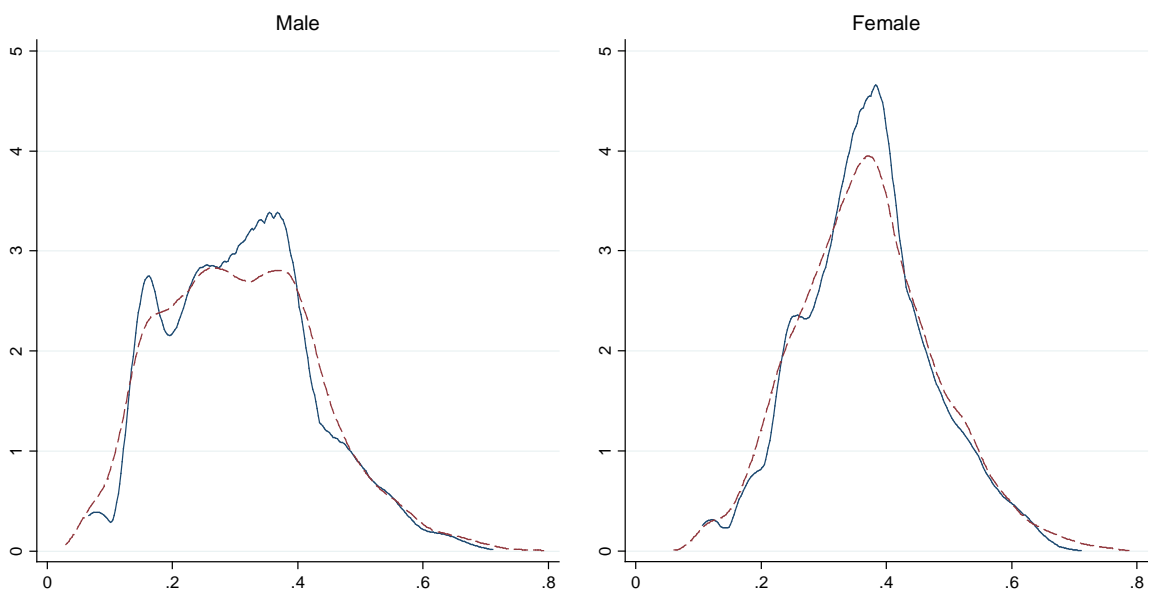

Note: the vertical axis plots the kernel density (\%) and the horizontal axis plots predicted probability of internal loan. The solid line represents $E(d \mid \mathrm{X})$ series and the dotted line represents $E(d \mid X, R)$ series. The means for males and females are 0.31 and 0.37 , respectively.

TABLE 3. COEFFICIENTS OF $\hat{d}$

\begin{tabular}{|c|c|c|c|c|c|c|c|}
\hline \multirow[b]{2}{*}{ No } & \multirow[b]{2}{*}{ Model } & \multicolumn{3}{|l|}{ Male } & \multicolumn{3}{|l|}{ Female } \\
\hline & & Coeff. & (s.e.) & $\mathrm{N}$ & Coeff. & (s.e.) & $\mathrm{N}$ \\
\hline 1 & $\hat{d}$ on Knowledge & 0.862 & $(0.193)^{* * *}$ & 11,959 & 0.237 & $(0.156)$ & 13,291 \\
\hline 2 & $\hat{d}$ on Borrow & -0.106 & $(0.238)$ & 9,382 & 0.558 & $(0.238)^{* *}$ & 8,973 \\
\hline 3 & $\begin{array}{l}\hat{d} \text { on Borrow for } \\
\text { business }\end{array}$ & -0.345 & $(0.355)$ & 8,456 & 0.578 & $(0.391)$ & 8,190 \\
\hline 4 & $\begin{array}{l}\hat{d} \text { on Borrow for } \\
\text { non-business }\end{array}$ & 0.001 & $(0.265)$ & 8,964 & 0.497 & $(0.259)^{*}$ & 8,650 \\
\hline 5 & $\begin{array}{l}\hat{d} \text { on Total loan } \\
\text { amount }\end{array}$ & 1.415 & $(0.672)^{* *}$ & 1,295 & -0.347 & $(0.760)$ & 1,085 \\
\hline
\end{tabular}
loan amount, the model is estimated using 2SLS (two stage least square).

To summarize the other results of formal credit activities in the knowledge equation, we note that educated individuals and those in the workforce are more likely to be aware of formal credit markets. Wealthier individuals and those actively involved in community activities are also more likely to be aware of formal providers. These results are not surprising. Employment and community participation also has strong positive effects in the borrowing equation for both males and females. Disaggregating formal sector borrowing by the purpose of the loan, we observe, unsurprisingly, that 
educated and self-employed individuals are more likely to borrow for business purposes. Consumption loans are more likely for individuals from female-headed households. Our analysis shows that for females, being employed in government jobs improves access to formal credit markets. This may be because they have better opportunities for obtaining loans and can ask for larger-sized loans. Education is another important factor that increases the likelihood of receiving larger loans.

\section{PREDICTIONS}

In this section, we use the estimated equations to assess the education strategy. To isolate the role of education, the effects of other socio-demographics were held constant at reference levels. Table 4 summarizes the characteristics for the reference male and female. Except for location and province, the levels were selected based on sample means or the majority case for binary variables.

TABLE 4. CHARACTERISTICS OF REFERENCE INDIVIDUALS

\begin{tabular}{lll}
\hline Socio-demographics & Male & Female \\
\hline Age & 36 & 36 \\
Marital status & Married & Married \\
Head of household & Yes & No \\
Muslim & Yes & Yes \\
\# adults & 4 & 4 \\
\# children & 1 & 1 \\
\# elderly (>=50 years) & 1 & 1 \\
Asset (log scale) & 16 & 16 \\
Employment & Self-employed & Not working \\
Community & activities & 2 in 5 \\
participated & No & 1 in 5 \\
Spouse working & Primary & Yes \\
Spouse education & Urban & Primary \\
Live in & Market, post-office, bank, no & Market, post-office, bank, no \\
Infrastructure & govt program & govt program \\
& Jakarta & Jakarta (capital) \\
Province & &
\end{tabular}

There is little dispute that internal loans have desirable properties from the borrower's perspective (e.g., they may not require collateral, there may be some repayment flexibility and the interest rates on borrowing may be low or have no interest requirement). However, since internal loans are not always available, policies that aim to improve access to formal credit markets would allow people to maintain their consumption pattern. Education in particular can be part of a strategy to increase 
an individual's knowledge of formal borrowing opportunities and improve their creditworthiness.

The interactions between knowledge of formal sector borrowing sources, expected access to internal loans, and education levels are depicted in Figure 2. As the reference individuals are effectively the "average" male or female, the slope at each point is effectively the marginal effects of expected access to internal loan on the likelihood of an external loan for individuals with different education levels. As expected, education generally increases knowledge of formal credit markets. In the male sample, less educated males, particularly those with no schooling, who expect to have higher access to internal loans, also have a high probability of seeking out formal sector loans. The lines get flatter at higher education levels, reaching a level close to one, suggesting that higher education reduces the role of internal networks on formal borrowing activities. At the mean $\hat{d}$ level of $40 \%$, the marginal effects range from a large value of 0.32 for males with no schooling to 0.05 for males with a college education. For females, the influence of internal loans is largely independent of education levels, but as in the case for males, there is a gradient for those with no schooling. At the $\hat{d}$ level of $40 \%$, the marginal effect for females with no schooling is 0.09. A comparison of the left and right panels of Figure 2 shows us the extent of the gender gap. In particular we observe females having a lower propensity of having knowledge of formal credit markets compared to males at any education level.

FIGURE 2. RESPONDENT'S EDUCATION AND KNOWLEDGE OF EXTERNAL LOAN SOURCES, ACCESS TO INTERNAL LOANS
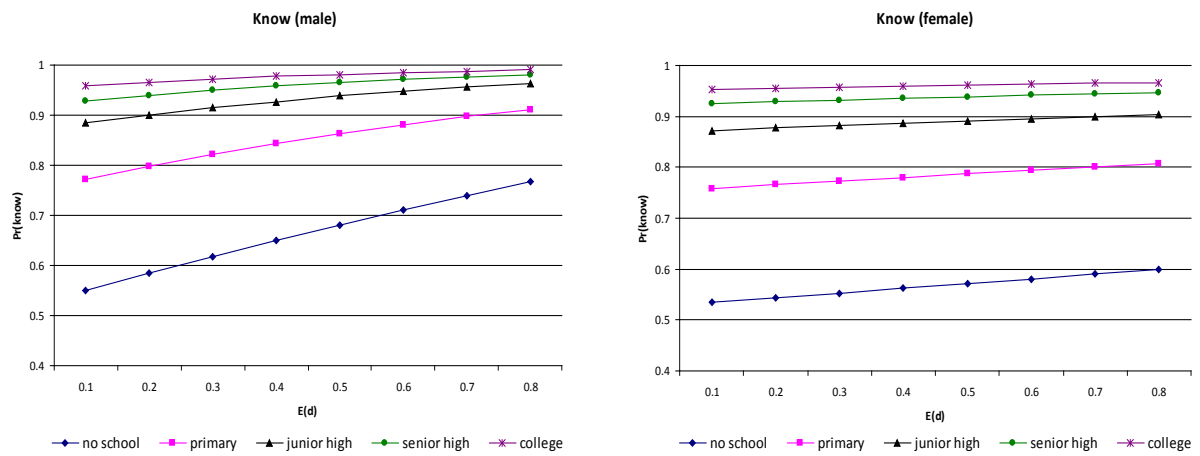

Note: each line represents the knowledge propensity for the reference individual.

Figure 3 depicts the interactions between borrowing activities and expected access to internal loans for respondents of different education levels. The distinct trend in female and male borrowing behavior is clear. For males, there is a modest negative relationship between $\hat{d}$ and borrowing for business purposes. Among females, we note that the relationship between external borrowing and $\hat{d}$ is positive. Furthermore, borrowing by females is more sensitive to $\hat{d}$ than otherwise similar males (as 
suggested by steeper lines). We speculate that one explanation for this may be because internal networks improve a female respondent's access to information on formal credit markets.

In Figure 3, the lowest line, for both types of loans and for both males and females, are referring to those with no formal schooling. This suggests that education is crucial in influencing access to formal credit institutions. Females with no schooling have a very low probability of borrowing for business purposes. It is worth noting that better educated females have a substantially higher probability of borrowing in formal markets, even relative to reference males with a college education.

Borrowing for non-business purposes by male respondents is insensitive to their expectations of internal loans. For females, just as in the case of business loans, we find that the propensity to borrow in the formal sector increases with greater expectations of access to internal loans. Upward sloping curves are consistent with the loan sources being complements. However, as we observe, the lines are flatter for higher educated females (senior high or college graduates). In other words, education reduces a female respondent's dependency on internal loans.

\section{FIGURE 3. RESPONDENT'S EDUCATION LEVEL AND FORMAL SECTOR BORROWING}

Borrow for business (male)

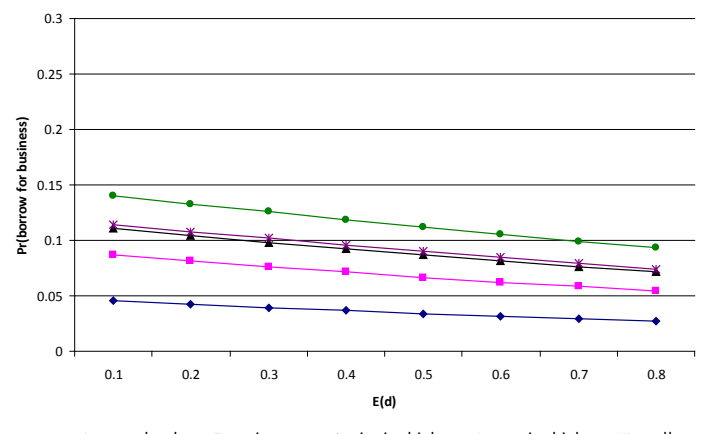

Borrow for non-business (male)

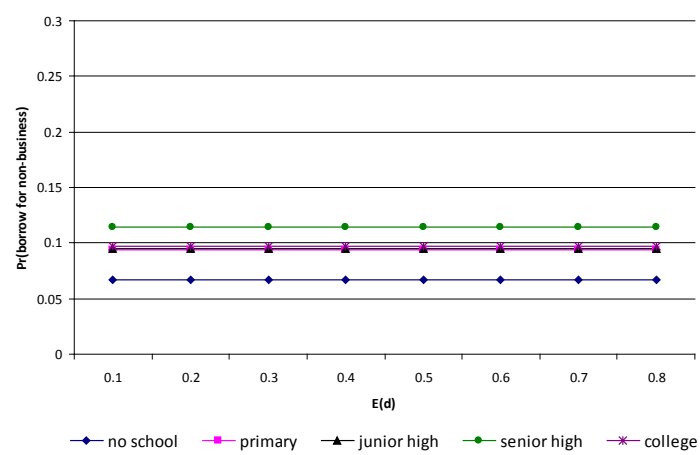

Borrow for business (female)

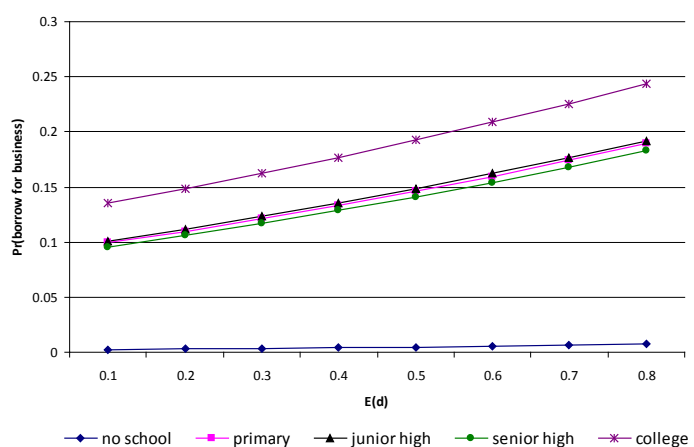

Borrow for non-business (female)

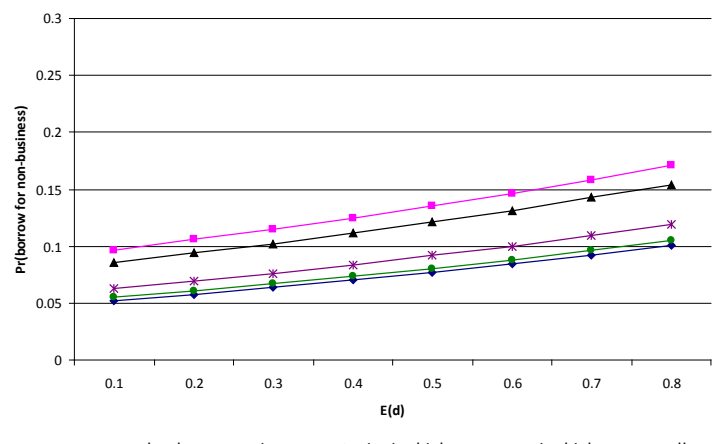


In this paper using data from Indonesia, we analyzed the relationship between access to internal loans and borrowing behavior in the formal credit market. For some individuals, specifically those with high expectations of receiving an internal loan, the requirement for external loans may be expected to be secondary. We test this prediction and analyze external loan activities for different levels of access to internal loan.

The main results from our analysis can be summarized as follows: First, we note gender differences in borrowing behavior. Specifically we find that access to internal loans is different for male and female respondents, with females having a higher expectation of receiving internal loans compared to males. There is some support for consumption-smoothing among family members, as we observe recipients of internal loans also being providers of internal loans. However, even among family members, we find that the economic characteristics of the borrowers play a crucial role in their likelihood of receiving an internal loan. Empirically we find that access to internal loans does not adversely affect an individual's propensity to seek credit in the formal market. On the other hand, the expectation of internal loans increases the likelihood of improving information on formal credit sources, particularly for males. Furthermore, we find that the borrowing propensity in formal credit markets for males is not affected by their expected access to internal loans, and also increases the size of the amount that they borrow in the formal sector. For females, the pattern is different, with expectations of an internal loan increasing the propensity to borrow. We also note that the borrowing propensity of females in formal credit markets is positively related to their ability to access internal loans. This positive relationship suggests that loans from internal networks and the formal credit market act as complements rather than substitutes.

Several policy implications flow from our study. Firstly, the benefits of having microcredit programs targeted at women have been successfully demonstrated in the case of Bangladesh, India and Bolivia. Our study has established large gender differences in respondent's ability to identify formal sector credit institutions, with employed women in particular having better access to formal credit facilities. This suggests that formal sector lenders face large screening and monitoring costs, and therefore prefer lending to employed women to ensure regular repayments. The introduction of a microcredit program modelled along the lines of Bangladesh's successful Grameen Bank would reduce informational asymmetries. The microcredit programs can be implemented through community programs like sponsorship of women's group and having field workers (could be the women themselves who have been successful) to monitor performance. For example, microcredit institutions typically use a group-lending mechanism, replicating the village-lending tradition, which relies on self-formed groups to minimize asymmetric information problems, through the use of peer-screening, social pressure and peer-monitoring. Furthermore, the small regular repayment schedules imposed by microcredit institutions allow women to partition their commitments into manageable levels. Similarly, dynamic incentives, which reward good credit history in the form of possibilities for larger loan amounts in future, ensures continuing creditworthiness of their borrowers.

Secondly, we note that contingent on knowledge of formal sector institutions, a relatively higher proportion of women borrowed from informal credit sources. From our descriptive statistics we observe that $30 \%$ of the female respondents borrowed for business purposes and approximately $14 \%$ of women work in unpaid family business. 
This highlights an entrepreneurial spirit among Indonesian women, and indicates perhaps an unmet need for credit. The implementation of microcredit programs along the lines described above would be welfare-enhancing under these circumstances.

Finally, our study has highlighted the important role of education and social networks. Our results show that at any education level, females have a lower likelihood of having knowledge of formal sector credit markets compared to males. Policy initiatives to promote education will have the effect of improving knowledge of formal credit markets, which in turn may lower demand for internal loans and subsequently close the gender gap in access to formal credit markets. 


\section{ENDNOTES}

1. An internal loan is defined as monetary transfers (loans or tuition) excluding values of in-kind transfers such as food items from any of non-coresiding parent(s), sibling(s), or child(ren) in the last 12 months.

2. It is a targeted credit-plus extension program of the Ministry of Agriculture with sponsors from Food and Agriculture Organization (FAO) and International Fund for Agricultural Development (IFAD).

3. In our dataset, information on transfers between coresiding family members is not available. Moreover, these types of transfers are difficult to record anyway as they happen regularly. Hence, for the rest of the paper internal networks refer to noncoresiding family members. We use the terms internal loans and internal transfers interchangeably as it is not possible to distinguish between transfers requiring compulsory repayment and those without compulsory repayment schedule from the questionnaire. Internal transfers can be seen as a form of internal loan with negative interest rates.

4. The specific question in the survey asks "Other than family/friends do you know of a place where you can borrow money?” Those individuals who answered 'yes' to this question are defined as being "knowledgeable". Knowledgeable individuals were then asked a series of questions on their borrowing history. Respondents who answered 'no' $(K=0)$ were not asked any further questions on credit markets.

5. The model is estimated in STATA using ivprobit routine by Harkness (2004) which implements AGLS using Maximum Likelihood.

6. These results are not presented here but are available from the authors on request.

7. Only up to three borrowing activities can be recorded. Our data indicates that $72 \%$ of borrowers had made one attempt to borrow, and $96 \%$ had at most three attempts.

8. The test used to determine the plausibility of pooling was based on log-likelihood comparisons following Swait and Louviere (1993). For instance, to achieve poolability of the amended model, variables for males have to be scaled by 0.88 . The test for equality in parameters cannot be rejected following chi-sq distribution with 27 degrees of freedom (p-value of 0.6 ) and the test for equality in scale is rejected with ample evidence.

9. Information on the exact pair of provider and recipient is not available. Hence, the provision of loans can be to any other family members, including the respondent. 


\section{APPENDIX A. DESCRIPTIVE STATISTICS AND VARIABLE DEFINITIONS}

FOR KEY VARIABLES

\begin{tabular}{|c|c|c|c|}
\hline & $\begin{array}{l}\text { Full } \\
\text { sample }\end{array}$ & Male & Female \\
\hline $\begin{array}{l}\text { Know= } 1 \text { if the respondent is able to identify an external (non- } \\
\text { family) source of credit }\end{array}$ & 0.727 & 0.785 & 0.675 \\
\hline $\begin{array}{l}\text { Borrow }=1 \text { if the respondent attempted to borrow from external } \\
\text { provider in the last } 12 \text { months (out of know=1) }\end{array}$ & 0.133 & 0.143 & 0.123 \\
\hline $\begin{array}{l}\text { Borrow business= } 1 \text { if the respondent attempted to borrow for } \\
\text { business purposes (out of know=1) }\end{array}$ & 0.045 & 0.049 & 0.039 \\
\hline $\begin{array}{l}\text { Borrow non-business }=1 \text { if the respondent attempted to borrow } \\
\text { for non-business purposes (out of know }=1 \text { ) }\end{array}$ & 0.097 & 0.103 & 0.091 \\
\hline $\begin{array}{l}\text { Received family loan= } 1 \text { if the respondent borrowed from } \\
\text { family members }\end{array}$ & 0.341 & 0.309 & 0.369 \\
\hline Loan amount in million Rp (only for borrowers) & $\begin{array}{l}2.257 \\
(13.800)\end{array}$ & $\begin{array}{l}3.038 \\
(18.500)\end{array}$ & $\begin{array}{l}1.324 \\
(2.749)\end{array}$ \\
\hline Female $=1$ if female & 0.526 & & \\
\hline Age in years & $\begin{array}{l}36.310 \\
(16.438)\end{array}$ & $\begin{array}{l}36.259 \\
(16.405)\end{array}$ & $\begin{array}{l}36.356 \\
(16.467)\end{array}$ \\
\hline HH head=1 if respondent is household head & 0.347 & 0.602 & 0.118 \\
\hline Married $=1$ if the respondent is married & 0.649 & 0.661 & 0.638 \\
\hline $\begin{array}{l}\text { Separated/widowed }=1 \text { if the respondent was previously } \\
\text { married but is now either separated or widowed }\end{array}$ & 0.091 & 0.030 & 0.145 \\
\hline Religion $=1$ if Muslim & 0.887 & 0.885 & 0.888 \\
\hline $\begin{array}{l}\text { Provided family loan= } 1 \text { if the respondent provided loan to } \\
\text { family }\end{array}$ & 0.399 & 0.416 & 0.383 \\
\hline Primary= 1 if highest edu. level is Primary & 0.406 & 0.396 & 0.414 \\
\hline Junior High= 1 if respondent's highest edu. level is Junior high & 0.168 & 0.182 & 0.155 \\
\hline Senior high= 1if respondent's highest edu. level is Senior high & 0.238 & 0.268 & 0.212 \\
\hline $\begin{array}{l}\text { Post-school=1 if respondent's highest edu. level is college or } \\
\text { university }\end{array}$ & 0.080 & 0.092 & 0.067 \\
\hline Number of adults in the household (aged 15 - 50) & $\begin{array}{l}3.645 \\
(2.105)\end{array}$ & $\begin{array}{l}3.702 \\
(2.143)\end{array}$ & $\begin{array}{l}3.594 \\
(2.068)\end{array}$ \\
\hline Number of children in the household (aged $<15$ ) & $\begin{array}{l}1.446 \\
(1.314)\end{array}$ & $\begin{array}{l}1.427 \\
(1.314)\end{array}$ & $\begin{array}{l}1.464 \\
(1.314)\end{array}$ \\
\hline Number of elderly in the household (aged $>50$ ) & $\begin{array}{l}1.002 \\
(0.989)\end{array}$ & $\begin{array}{l}0.982 \\
(0.992)\end{array}$ & $\begin{array}{l}1.021 \\
(0.986)\end{array}$ \\
\hline Family worker= 1 if unpaid and works for family & 0.104 & 0.065 & 0.140 \\
\hline Public worker $=1$ if employed in Public sector & 0.045 & 0.063 & 0.029 \\
\hline Private worker $=1$ if employed in Private sector & 0.253 & 0.343 & 0.172 \\
\hline Self-employed = 1 if self-employed & 0.277 & 0.351 & 0.210 \\
\hline Log (Rp.asset) & $\begin{array}{l}16.252 \\
(2.233)\end{array}$ & $\begin{array}{l}16.237 \\
(2.256)\end{array}$ & $\begin{array}{l}16.267 \\
(2.212)\end{array}$ \\
\hline Participation/available community activities & 0.296 & 0.440 & 0.167 \\
\hline Spouse Primary= 1 if highest edu. Level of spouse is Primary & 0.285 & 0.307 & 0.266 \\
\hline
\end{tabular}


Spouse Junior High= 1 if spouse's highest edu. level is Junior

high

Spouse Senior high= 1if spouse's highest edu. level is Senior

high

Spouse Post-school=1 if spouse's highest edu. level is some

college or university

Spouse work $=1$ if spouse is in employment

Father dead=1 if respondent's father (only) is dead

Mother dead=1 if respondent's mother (only) is dead

Parent dead=1 if respondent's parents are both dead

Number of siblings that are employed

Number of siblings that the respondent sees regularly

Number of siblings live nearby

No non-coresiding siblings

Sibling's mean age

Urban

$\mathrm{Km}$ to nearest market

$\mathrm{Km}$ to nearest post office

Km to nearest Financial Institution

Sample size $\mathrm{e}^{\mathrm{a}}$

\begin{tabular}{|c|c|c|}
\hline 0.091 & 0.098 & 0.086 \\
\hline 0.112 & 0.104 & 0.119 \\
\hline 0.040 & 0.033 & 0.046 \\
\hline 0.397 & 0.289 & 0.493 \\
\hline 0.459 & 0.452 & 0.466 \\
\hline 0.310 & 0.304 & 0.315 \\
\hline 0.252 & 0.247 & 0.256 \\
\hline $\begin{array}{l}0.189 \\
(0.623)\end{array}$ & $\begin{array}{l}0.193 \\
(0.639)\end{array}$ & $\begin{array}{l}0.186 \\
(0.609)\end{array}$ \\
\hline 1.671 & 1.655 & 1.686 \\
\hline (2.086) & (2.091) & (2.081) \\
\hline 1.560 & 1.524 & 1.593 \\
\hline (2.032) & (2.032) & (2.031) \\
\hline 0.299 & 0.320 & 0.280 \\
\hline 24.992 & $\begin{array}{l}24.618(2 \\
221)\end{array}$ & $\begin{array}{l}25.328 \\
(2177)\end{array}$ \\
\hline $\begin{array}{l}(21.980) \\
0.377\end{array}$ & $\begin{array}{l}2.21) \\
0.375\end{array}$ & $\begin{array}{l}(21.77) \\
0.379\end{array}$ \\
\hline $\begin{array}{l}1.496 \\
(2.612)\end{array}$ & $\begin{array}{l}1.489 \\
(2.592)\end{array}$ & $\begin{array}{l}1.503 \\
(2.629)\end{array}$ \\
\hline 3.761 & 3.663 & 3.849 \\
\hline (8.423) & (8.112) & (8.692) \\
\hline 4.226 & 4.248 & 4.207 \\
\hline (9.570) & (9.837) & (9.325) \\
\hline 25250 & 11959 & 13291 \\
\hline
\end{tabular}

${ }^{\mathrm{a}}$ All adults in the survey including those with missing information for some variables. There are missing dummies for asset and community identifier, and for these observations, log of asset and community-level variables are replaced by zero. For spouse's characteristics, those without spouse have zero values, and the dummy for marital status essentially capture the fact that for non-married individuals, these variables are irrelevant. Kukesra stands for Prosperous Family Loans Program. It is a government-run program providing loans to poor families. 
APPENDIX B: TABLE 1B. PROBIT COEFFICIENTS ON KNOWLEDGE AND BORROWING EQUATIONS

\begin{tabular}{|c|c|c|c|c|}
\hline & \multicolumn{2}{|l|}{ Knowledge } & \multicolumn{2}{|l|}{ Borrow } \\
\hline & Male & Female & Male & Female \\
\hline E(internal loan) & $0.862 * * *$ & 0.237 & -0.106 & $0.558 * *$ \\
\hline Age & $0.039 * * *$ & $0.034 * * *$ & $0.032 * * *$ & $0.054 * * *$ \\
\hline Agesq & $-0.000 * * *$ & $-0.000 * * *$ & $-0.000 * * *$ & $-0.000 * * *$ \\
\hline Household head & $0.122 * *$ & $0.199 * * *$ & $0.136^{* *}$ & 0.107 \\
\hline Married & $-0.162 * *$ & -0.084 & 0.144 & $0.377 * * *$ \\
\hline Separated/divorced & $-0.221 * *$ & -0.082 & 0.097 & $0.176^{*}$ \\
\hline Muslim & 0.014 & 0.076 & 0.109 & -0.047 \\
\hline Primary & $0.621 * * *$ & $0.616^{* * *}$ & $0.272 * *$ & $0.218^{* * *}$ \\
\hline Junior high & $1.069 * * *$ & $1.052 * * *$ & $0.333 * * *$ & $0.164 *$ \\
\hline Senior high & $1.343 * * *$ & $1.360 * * *$ & $0.447 * * *$ & -0.024 \\
\hline Post-school & $1.614^{* * *}$ & $1.584 * * *$ & $0.333^{* *}$ & 0.086 \\
\hline \# adults & 0.013 & -0.008 & 0.007 & 0.013 \\
\hline \# children & $-0.024 * *$ & $-0.019 *$ & 0.018 & 0.025 \\
\hline \# elderly & -0.014 & -0.022 & 0.003 & $-0.047 * *$ \\
\hline Log (HH asset) & $0.090 * * *$ & $0.093 * * *$ & $-0.035^{* * *}$ & -0.005 \\
\hline Community participation & $0.096 * *$ & 0.079 & $0.207 * * *$ & $0.520 * * *$ \\
\hline Spouse working & 0.002 & -0.021 & 0.033 & 0.033 \\
\hline Spouse primary & 0.082 & $0.089 *$ & 0.091 & -0.005 \\
\hline Spouse junior high & $0.316^{* * *}$ & $0.207 * * *$ & $0.167 * *$ & 0.013 \\
\hline Spouse senior high & $0.316^{* * *}$ & $0.272 * * *$ & $0.155^{*}$ & $0.178 * *$ \\
\hline Spouse post-school & $0.320 * *$ & $0.370 * * *$ & 0.152 & 0.018 \\
\hline Self-employed & $0.164 * * *$ & $0.226 * * *$ & $0.425 * * *$ & $0.436 * * *$ \\
\hline Unpaid workers & 0.014 & $0.119 * * *$ & 0.158 & $0.191 * * *$ \\
\hline Public workers & $0.551 * * *$ & $0.777 * * *$ & $1.053 * * *$ & $1.083^{* * *}$ \\
\hline Private workers & $0.246 * * *$ & $0.195^{* * *}$ & $0.534 * * *$ & $0.573 * * *$ \\
\hline Urban & 0.027 & $0.106^{* * *}$ & 0.052 & $0.180 * * *$ \\
\hline Have Kukesra program & $0.132 * * *$ & 0.041 & & \\
\hline IDT village & 0.068 & 0.061 & & \\
\hline $\mathrm{km}$ from nearest market & $-0.020 * * *$ & $-0.033 * * *$ & & \\
\hline $\mathrm{km}$ from nearest post & $-0.006 * * *$ & -0.003 & & \\
\hline $\mathrm{km}$ from nearest bank & 0.002 & -0.001 & & \\
\hline Constant & $-2.969 * * *$ & $-2.761 * * *$ & $-2.567 * * *$ & $-3.711 * * *$ \\
\hline $\mathrm{N}$ & 11959 & 13291 & 9382 & 8973 \\
\hline $\log L$ & -5100 & -6601 & -3382 & -2790 \\
\hline d.f. & 45 & 45 & 39 & 39 \\
\hline
\end{tabular}




\section{APPENDIX B: TABLE 2B. PROBIT COEFFICIENTS ON BORROWING FOR BUSINESS AND NON-BUSINESS AND OLS ON LOAN AMOUNT}

\begin{tabular}{|c|c|c|c|c|c|c|}
\hline & \multicolumn{2}{|l|}{ Business } & \multicolumn{2}{|c|}{ Non-business } & \multicolumn{2}{|c|}{ Log(amount) } \\
\hline & Male & Female & Male & Female & Male & Female \\
\hline E(internal loan) & -0.345 & 0.578 & 0.001 & $0.497 *$ & $1.415^{* *}$ & -0.347 \\
\hline Age & $0.062 * * *$ & $0.043 * * *$ & $0.018^{*}$ & $0.056 * * *$ & $0.110^{* * *}$ & $0.059 * * *$ \\
\hline Agesq & $-0.001^{* * *}$ & $-0.000 * *$ & 0.000 & $-0.000 * * *$ & $-0.001 * * *$ & $-0.001^{* *}$ \\
\hline Household head & 0.155 & -0.016 & 0.123 & 0.147 & 0.253 & 0.263 \\
\hline Married & 0.054 & $0.507 * * *$ & $0.178 *$ & $0.338 * * *$ & 0.121 & 0.263 \\
\hline Separated/divorced & 0.23 & $0.458 * *$ & 0.024 & 0.088 & 0.053 & 0.343 \\
\hline Muslim & -0.053 & -0.086 & $0.202^{* *}$ & -0.037 & -0.271 & -0.186 \\
\hline Primary & $0.325^{*}$ & $0.310^{* *}$ & 0.181 & $0.148^{*}$ & $0.445 *$ & $0.350 *$ \\
\hline Junior high & $0.463^{* *}$ & $0.320 * *$ & 0.184 & 0.08 & $0.841^{* * *}$ & $0.601 * * *$ \\
\hline Senior high & $0.610^{* * *}$ & $0.288^{*}$ & $0.293 * *$ & -0.153 & $0.991 * * *$ & $0.953 * * *$ \\
\hline Post-school & $0.485 * *$ & $0.495 * *$ & 0.201 & -0.082 & $1.230 * * *$ & $1.257 * * *$ \\
\hline \# adults & 0.001 & 0.001 & 0.008 & $0.021^{*}$ & 0.017 & -0.009 \\
\hline \# children & -0.008 & 0.012 & $0.029 *$ & 0.026 & -0.021 & -0.063 \\
\hline \# elderly & 0.02 & -0.032 & -0.004 & $-0.050 *$ & -0.068 & $-0.086^{*}$ \\
\hline Log (HH asset) & 0.022 & 0.038 & $-0.057 * * *$ & -0.023 & $0.359 * * *$ & $0.213^{* * *}$ \\
\hline Comm. participation & $0.196^{* * *}$ & $0.393 * * *$ & $0.188 * * *$ & $0.536^{* * *}$ & $-0.271^{* *}$ & -0.159 \\
\hline Spouse working & $0.149 * *$ & 0.159 & -0.033 & -0.031 & 0.097 & 0.159 \\
\hline Spouse primary & $0.177^{*}$ & -0.041 & 0.04 & -0.009 & 0.031 & 0.112 \\
\hline Spouse junior high & 0.169 & -0.011 & 0.135 & -0.001 & -0.052 & 0.209 \\
\hline Spouse senior high & 0.123 & 0.014 & 0.124 & $0.230 * *$ & 0.104 & $0.403^{* *}$ \\
\hline Spouse post-school & 0.196 & -0.282 & 0.119 & 0.136 & 0.334 & $0.383^{*}$ \\
\hline Self-employed & $0.868 * * *$ & $1.026 * * *$ & 0.092 & 0.053 & -0.02 & $0.215^{*}$ \\
\hline Unpaid workers & $0.616^{* * *}$ & $0.640 * * *$ & -0.091 & -0.043 & -0.344 & -0.006 \\
\hline Public workers & $0.658^{* * *}$ & $0.572 * * *$ & $1.139 * * *$ & $1.130 * * *$ & 0.341 & $0.802 * * *$ \\
\hline Private workers & $0.274 *$ & $0.266 * *$ & $0.581 * * *$ & $0.575 * * *$ & $-0.564 *$ & -0.156 \\
\hline Urban & 0.000 & 0.081 & 0.074 & $0.196 * * *$ & -0.094 & $-0.222 * *$ \\
\hline constant & $-4.460^{* * *}$ & $-5.114^{* * *}$ & $-2.130 * * *$ & $-3.394 * * *$ & $4.081 * * *$ & $7.445^{* * *}$ \\
\hline $\mathrm{N}$ & 8456 & 8190 & 8964 & 8650 & 1295 & 1085 \\
\hline $\log L$ & -1423 & -1096 & -2553 & -2160 & -2331 & -1853 \\
\hline
\end{tabular}




\section{REFERENCES}

Adkins, L. C., 2008, Small Sample Performance of Instrumental Variables Probit Estimators: A Monte Carlo investigation. Department of Economics, Oklahoma State University [online; cited August 2009.] Available from URL: http://www.learneconometrics.com/pdf/JSM2008.pdf

Adkins, L. C., 2009, Instrumental Variables Probit Estimators Using gretl. Department of Economics, Oklahoma State University [online; cited August 2009.] Available from URL: http://www.learneconometrics.com/pdf/GC2009.pdf

Banerjee, Abhijit; Esther Duflo; Rachel Glennerster; and Cynthia Kinnan. 2009. The Miracle of Microfinance? Evidence from a Randomised Evaluation. Poverty ActionLabWorking Paper no. 101. Cambridge, Mass.: Massachusetts Institute of Technology.

Berger, M., 1989. Giving Women Credit: The Strengths and Limitations of Credit as a Tool for Alleviating Poverty. World Development, 17:7, pp. 1017-1032.

Chemin, M., 2003, The Benefits (and costs) of Microfinance. London School of Economics, draft.

Conning, Jonathan, and Christopher Udry. 2007. Rural Financial Markets in DevelopingCountries. In Handbook of Agricultural Economics Vol. 3, ed. Robert Evenson andPrabhu Pingali. Amsterdam: North-Holland.

Gertler, Paul, David Levine, and Enrico Moretti, 2001, Do Microfinance Programs Help Families Insure Consumption Against Illness?. mimeo, Department of Economics, UCLA.

Halder, S and P. Mosley, 2004, Working With the Ultra Poor: Learning From BRAC Experiences. Journal of International Development, 16, pp. 387-406.

Hamada, Miki. 2010. Financial Services to the Poor: An Introduction to the Special Issue on Microfinance. Developing Economies 48, no. 1: 1-14.

Hashemi, S. M., S. R. Schuler and A. P. Riley, 1996, Rural Credit Programs and Women's Empowerment in Bangladesh. World Development, 24:4, pp. 635-653.

Johnston, D and J. Morduch, 2007, Microcredit vs. Microsaving: Evidence from Indonesia. mimeo, New York University.

Karlan, Dean, and Jonathan Zinman. 2009 Expanding Microenterprise Credit Access: Using Randomized Supply Decisions to Estimate the Impacts in Manila. BREAD Working Paper no. 235.

Kim, J. and A. Aassve, 2006, Fertility and its Consequence on Family Labor Supply. IZA DP No. 2162.

Khawari, A., 2004, Microfinance: Does it hold its promises A survey of recent literature. Hamburg Institute of International Economics (HWWA) Discussion Paper No.276.

Maddala, G., 1983, Limited-Dependent and Qualitative Variables in Econometrics. Cambridge University Press.

Okten, C. and U. O. Osili, 2004, Social Networks and Credit Access in Indonesia. World Development, 32:7, pp.1225-1246. 
Panjaitan-Drioadisuryo,R.D.M. and K. Cloud, 1999, Gender, Self-employment and Microcredit Programs: An Indonesian Case Study. The Quarterly Review of Economics and Finance, 39, pp.769-779.

Pitt, M. M. and S. R. Khander, 1998, The Impact of Group Based Credit Programs on Poor Households in Bangladesh: Does the Gender of Participants Matter?. Journal of Political Economy, 106:3, pp.958-995.

Ravisc, R.M., 1999, Searching for Sustainable Microfinance: A Review of Five Indonesian Initiatives. Development Economics Research Group, Indonesia.

Sharma, M., 2002, Microfinance: Reaching Poor Rural Women. The International Food Policy Research Institute (IFPRI) 2020 Book Chapter 31.

Takahashi, K; Takayuki Higashikata, T and Tsukada, K 2010. The Short-Term Poverty Impact of Small-scale, Collateral-Free Microcredit in Indonesia: A Matching Estimator Approach, The Developing Economies 48, no. 1 (March): 128-55

Swait, J. and J. Louviere, 1993, The Role of the Scale Parameter in the Estimation and Comparison of Multinomial Logit Models. Journal of Marketing Research, 30, pp.305-314.

Webb, P., J. Coates, and R. Houser, 2002, Does Microcredit Meet the Needs of all Poor Women? Constraints to Participation Among Destitute Women in Bangladesh. The Gerald J. and Dorothy R. Friedman School of Nutrition Science and Policy, Discussion Paper No. 3.

Widarti, Diah, 1998, Determinants of Labour Force Participation by Married Women: The Case of Jakarta. Bulletin of Indonesian Economic Studies, 34:2, pp. 93 120. 